\title{
THE EFFICACY OF CLONIDINE IN THE PHARMACOLOGICAL MANAGEMENT OF ALCOHOL WITHDRAWAL SYNDROME: PRELIMINARY RESULTS
}

\author{
VIRGIL RADU ENĂTESCU ${ }^{1 \#}$, RALUKA KALINOVIC $^{2 \#}$, CRISTINA ADRIANA DEHELEAN $^{3}$, \\ CĂTĂLINA GIURGI-ONCU ${ }^{1}$, LAVINIA MARIA HOGEA ${ }^{1}$, PETRU IFTENI ${ }^{4}$, GABRIELA VLAD ${ }^{2}$, \\ OANA NEDA-STEPAN ${ }^{2}$, MIHAELA SIMU ${ }^{1}$, OVIDIU HOREA BEDREAG ${ }^{5}$, ILEANA MARINESCU ${ }^{6}$, \\ DELIA HUTANU $^{7}$, ILEANA ENĂTESCU ${ }^{8 *}$, LAURA ALEXANDRA NUSSBAUM $^{1}$
}

\author{
${ }^{I}$ The $8^{\text {th }}$ Department, Faculty of Medicine, "Victor Babeș” University of Medicine and Pharmacy, Timişoara, Romania \\ 2 "Pius Brinzeu” Emergency County Hospital - Psychiatric Clinic, Timișoara, Romania \\ ${ }^{3}$ The $2^{\text {nd }}$ Department, Faculty of Pharmacy, "Victor Babeș" University of Medicine and Pharmacy, Timișoara, Romania \\ ${ }^{4}$ Transilvania University, Braşov, Romania \\ ${ }^{5}$ The $10^{\text {th }}$ Department, Faculty of Medicine, "Victor Babeș" University of Medicine and Pharmacy, Timișoara, Romania \\ ${ }^{6}$ University of Medicine and Pharmacy Craiova, Romania \\ ${ }^{7}$ Biology Department, West University Timișoara, Romania \\ ${ }^{8}$ The $12^{\text {th }}$ Department, Faculty of Medicine, "Victor Babeș" University of Medicine and Pharmacy, Timișoara, Romania
}

*corresponding author: enatescu.ileana@umft.ro

${ }^{\#}$ Authors with equal contribution.

Manuscript received: February 2020

\begin{abstract}
Alcohol dependence and harmful use represent the most prevalent addictive disorder worldwide. Alcohol withdrawal syndrome is considered a life-threatening condition by inducing severe physiological imbalances. Pharmacological management of alcohol withdrawal syndrome is very complex and challenging, often involving a long duration in getting remission. Our ongoing study aimed to analyse the efficacy of clonidine (an alpha-2-agonist) for improving alcohol withdrawal syndrome quantified by the mean change of The Clinical Institute Withdrawal Assessment of Alcohol Scale, Revised (CIWA-Ar) scores. Of 30 patients with alcohol withdrawal syndrome recruited so far, 11 (36.7\%) benefited from clonidine treatment. Blood pressure and other physiological signs were periodically monitored. Although at the beginning of the treatment there were no differences between the mean CIWA-Ar scores $(t=0.352, p=0.599)$, after 5 days the difference became significant in favour of those treated with clonidine $(t=3.147, p=0.004)$. Clonidine may provide additional benefit in managing alcohol withdrawal by offering a different mechanism of action for targeting withdrawal symptoms.
\end{abstract}

\section{Rezumat}

Dependența de alcool și consumul dăunător de alcool reprezintă cele mai răspândite tulburări de adicție la nivel mondial. Sindromul de sevraj etanolic este considerat o afecțiune care pune viaţa în pericol prin inducerea unor dezechilibre fiziologice severe. Managementul farmacologic al sindromului de sevraj la alcool este foarte complex și provocator, implicând adesea o durată lungă de obținere a remisiunii. Studiul nostru în curs a urmărit să analizeze eficacitatea clonidinei (un agonist alfa-2) pentru ameliorarea sindromului de sevraj alcoolic cuantificată prin modificarea medie a scorurilor scalei The Clinical Institute Withdrawal Assessment of Alcohol Scale, Revised (CIWA-Ar). Din 30 de pacienți cu sindrom de sevraj alcoolic recrutaţi până în prezent, $11(36,7 \%)$ au beneficiat de tratament cu clonidină. Tensiunea arterială și alte semne fiziologice au fost monitorizate periodic. Deși la începutul tratamentului nu au existat diferențe între scorurile medii CIWA-Ar $(t=0,352, p=0,599)$, după 5 zile diferența a devenit semnificativă în favoarea celor trataţi cu clonidină $(t=3,147, p=0,004)$. Clonidina poate oferi beneficii suplimentare în gestionarea sevrajului la alcool, oferind un mecanism diferit de acțiune ce se adresează simptomelor de sevraj.

Keywords: alcohol withdrawal syndrome, clonidine, efficacy

\section{Introduction}

According to WHO data, in 2016, 2.3 billion (42\%) of people aged 15 or over were current drinkers meaning at least one use of alcohol in the past 12 months. Furthermore, in Romania, the alcohol consumption per capita (in litters of pure alcohol) was 12.6 in 2016, representing a downward trend compared to 2010 (15.0 litters of pure alcohol) but remains above
Europe's average of 9.8 litters per capita. The prevalence of alcohol use disorders and alcohol dependence in the Romanian population aged 15 and over, for the same year, were $2.8 \%$ and $1.3 \%$, respectively. In addition, 11,844 people in Romania died due to alcohol-attributable causes, of these 6,366 died from liver cirrhosis, 802 caused by road traffic injuries, and 4,676 due to cancer [1,2]. Alcohol 
FARMACIA, 2020, Vol. 68, 6

dependence is associated with a higher level of major depression and anxiety disorders, which contributes in a supplementary way to the devastating effect of this type of addiction. Furthermore, several clinical studies have found that in the Romanian population, the presence of depressive and anxiety symptoms is quite widespread, especially during the distinct critical period of life [3-5].

Alcohol withdrawal syndrome (AWS) is a frequent complication of those who met the criteria for alcohol dependence and its intensity may vary from symptoms such as insomnia, tremors, sweating, tachycardia up to more severe complications such as delirium or seizures implying 5 - 15\% mortality [6, 7].

Clonidine is the prototypical $\alpha 2$-adrenoreceptor agonist, with a higher affinity of 200:1 for $\alpha-2$ compared to $\alpha-1$ receptors, respectively. Initially used as a nasal decongestant, it is currently frequently used in the management of hypertension due to its ability to lower systemic blood pressure through central brainstem adrenergic stimulation. Clonidine is rapidly and almost completely absorbed after oral administration [8].

Several studies have noticed that autonomic hyperactivity in the CNS stands for an important physiological process underlying AWS. It is known that noradrenaline synthesis is enhanced in chronic alcohol abusers and during withdrawal $[9,10]$. A plethora of studies related to chronic alcohol administration and withdrawal from alcohol use have shown alterations in the central catecholamine levels; therefore, drugs that are able to decrease the autonomic hyperactivity in the brain are considered useful for the management of AWS $[11,12]$. Particularly, the $\alpha 2$-adrenoceptors subtypes are a specific $G$ protein ( $\mathrm{G}-\alpha$-i-coupled)mediated receptor and have an inhibitory auto-receptor effect on noradrenergic neurons simultaneously presynaptically and post-synaptically in the brain, brain stem, spinal cord, and peripheral nervous system [13]. According to certain reports that treatment with $\alpha-2$ adrenoceptor agonists, clonidine [14], lofexidine [15], and dexmedetomidine [16], decreases alcohol dependence/craving and withdrawal signs in both rodents and humans. All $\alpha 2$-adrenoceptors agents used clinically are imidazole derivatives and stimulate I1-imidazoline receptors in the brain and brain stem generating a sympatholytic effect $[17,18]$.

The current study aimed to investigate the efficacy of clonidine as adjunctive medication in the pharmacological treatment of patients having a diagnosis of AWS according to ICD-10 [19].

\section{Materials and Methods}

An ongoing study was carried out in 30 inpatients admitted in Timisoara Psychiatric Clinic I for AWS, Romania. Of these, 11 patients were given clonidine and 19 were treated without clonidine in therapeutic schema. All patients benefited from rehydration, B vitamins and hepato-protective medications. The sampling method was by convenience.

The severity of AWS was measured by using The Clinical Institute Withdrawal Assessment of Alcohol Scale, Revised (CIWA-Ar). This scale quantifies 10 symptoms of AWS. Scores of less than 8 to 10 indicate minimal to mild withdrawal. Scores of 11 to 15 indicate moderate withdrawal (marked autonomic arousal); and scores of 15 or more indicate severe withdrawal (impending delirium tremens) [20]. CIWA-Ar was administered twice, at the first day and at the $5^{\text {th }}$ day of continuous hospitalization and treatment.

Inclusion criteria consisted of patients aged 18 or above, meeting diagnostic criteria for alcohol withdrawal syndrome according to ICD-10. Exclusion criteria were represented by the lack of written informed consent, presence of pregnancy, presence of orthostatic hypotension, presence of confusion state at admission. However, 5 subjects have subsequently developed delirium state. The Local Ethics Committee for Scientific Research of the Timisoara County Emergency Hospital approved this study, and all participants were required to provide an informed consent.

Several blood tests were uniformly determined in all patients such as serum potassium concentrations, serum sodium concentrations, gamma-glutamyl transferase (GGT), alanine aminotransferase (ALT), aspartate aminotransferase (AST), total bilirubin, direct bilirubin, uric acid, and mean corpuscular volume (MCV).

The following analytes: GGT, ALT, AST, total bilirubin, direct bilirubin, uric acid were performed using Siemens Dimension RXL Max clinical chemistry system by spectrophotometry. Sodium and potassium ions were tested on the same analyser using the indirect ISE method. Regarding MCV we used flowcytometry method on Siemens Advia 2120 instrument. Statistical analysis

Statistical analyses were carried out by using STATA version 15 for Windows. Descriptive statistics were conducted dependent on analysis requirements. The Chi-squared test and Fischer Exact test were done to compare the frequencies of categorical variables. To compare the means of continuous data a two-tailed independent t-test was used. A non-parametric rank test (Mann-Whitney U-Test) was done to analyse categorical variables originating from two independent subsamples. Due to the non-normal distribution of CIWA-Ar scores, Spearman's rho correlation coefficients were calculated to establish the relation of these scores to the blood test results values.

\section{Results and Discussion}

Demographic data stratified by the presence of clonidine in the pharmacological treatment and family history of self-reported psychopathological conditions

The male gender distribution $(\mathrm{n}=28 ; 93.3 \%)$ was consistently more representative compared to the 
female gender $(\mathrm{n}=2 ; 6.7 \%)$; however, the gender distribution depending on the presence or absence of clonidine in the treatment was not statistically significant different $(\mathrm{p}=0.520)$ (Table I). However, it has to be mentioned that none of the women treated for AWS benefited from clonidine treatment. None of the other demographic characteristics were statistically significantly different. Hence, we can consider that the two strata were comparable from this perspective (Table I).

Table I

Demographic characteristics of the studied group depending on the clonidine treatment administration

\begin{tabular}{lccc}
\hline \multicolumn{1}{c}{ Sociodemographic data } & $\begin{array}{c}\text { Without clonidine } \\
(\mathbf{n = 1 9 )}\end{array}$ & $\begin{array}{c}\text { With clonidine } \\
(\mathbf{n}=\mathbf{1 1})\end{array}$ & Statistical significance \\
\hline Average current age (SD) & $51.05(7.856)$ & $53.55(10.172)$ & $\mathrm{p}=0.459$ \\
Gender - male, n (\%) & $17(89.5 \%)$ & $11(100.0 \%)$ & $\mathrm{p}=0.520$ \\
Educational level, mean ranks & 13.97 & 18.14 & $\mathrm{p}=0.158$ \\
Residency - Urban area, $\mathrm{n}(\%)$ & $3(27.3 \%)$ & $9(47.4 \%)$ & $\mathrm{p}=0.279$ \\
Professional status - Employed or Student, $\mathrm{n}(\%)$ & $7(63.6 \%)$ & $9(47.4 \%)$ & $\mathrm{p}=0.389$ \\
Marital status - with intimate partner, $\mathrm{n}(\%)$ & $6(54.5 \%)$ & $7(36.8 \%)$ & $\mathrm{p}=0.346$ \\
\hline
\end{tabular}

Note: The confidence interval (CI) is $95 \%$; The listed percentages are reported to either strata considered separately.

The correlations of AWS severity with different biologic indexes of blood tests

The severity of baseline AWS measured by CIWA-Ar total score was significantly positively correlated with the level of gamma-glutamyl transferase (GGT)

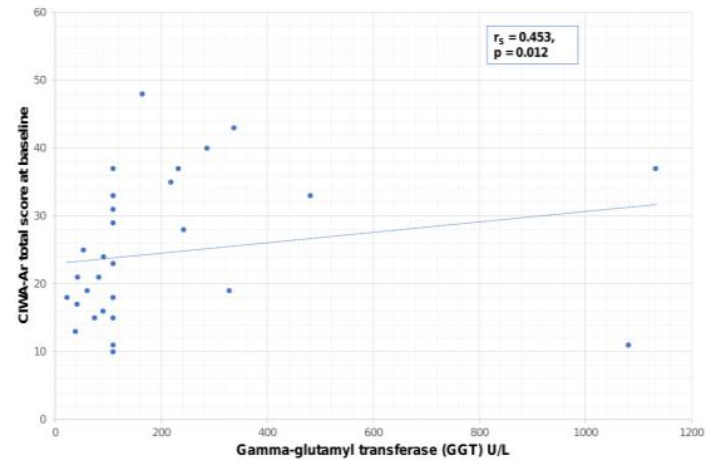

Figure 1.

Correlation between CIWA-Ar score at baseline and GGT levels
$\left(\mathrm{r}_{\mathrm{S}}=0.453, \mathrm{p}=0.012\right)($ Figure 1$)$ and alanine transaminase $(\mathrm{ALT})\left(\mathrm{r}_{\mathrm{S}}=0.450, \mathrm{p}=0.012\right)$ (Figure 2$)$ and inversely correlated with the level of potassium $\left(\mathrm{r}_{\mathrm{S}}=-0.429, \mathrm{p}=0.018\right)$ (Figure 3$)$.

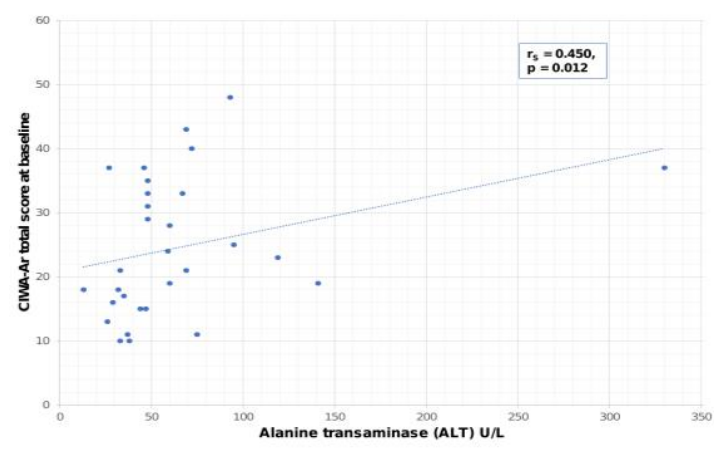

Figure 2.

Correlation between CIWA-Ar score at baseline and ALT levels

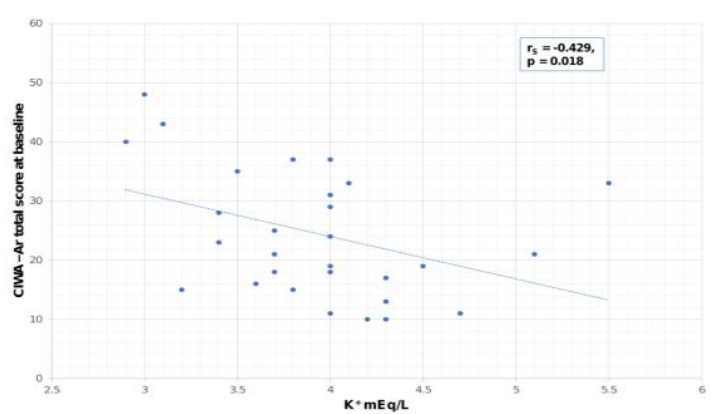

Figure 3.

Correlation between CIWA-Ar score at baseline and $\mathrm{K}^{+}$levels

At the $5^{\text {th }}$ day of hospitalization, we found that GGT remained strongly and constantly correlated $\left(r_{s}=0.654\right.$, $\mathrm{p}<0.001)$ with the severity of AWS measured by the same scale while AST was revealed as a new blood marker positively correlated with the severity of AWS $\left(r_{s}=0.384, p=0.036\right)($ Figures 4 and 5$)$. 


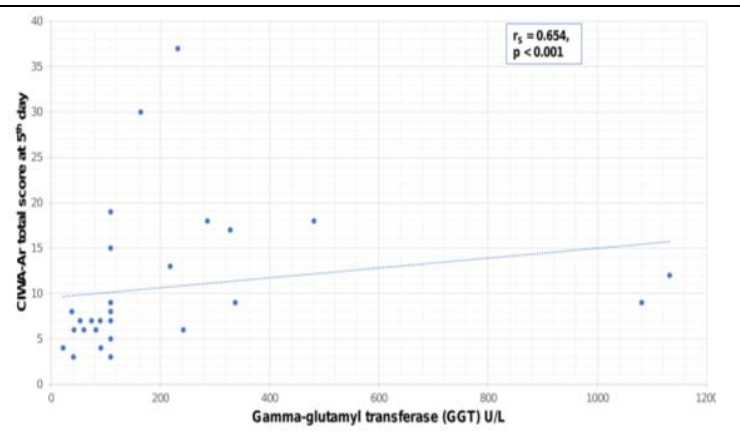

Figure 4.

Correlation between CIWA-Ar score at day 5 and GGT levels

The frequency, doses and efficacy of psychotropics used in managing AWS symptoms

Most of the enrolled patients have also benefited from treatment with benzodiazepines $(86.7 \%)$, followed by trazodone and tianeptine $(66.7 \%)$, anticonvulsants (63.3\%) and antipsychotics (43.3\%) (Table II). It is worth mentioning that trazodone was administered

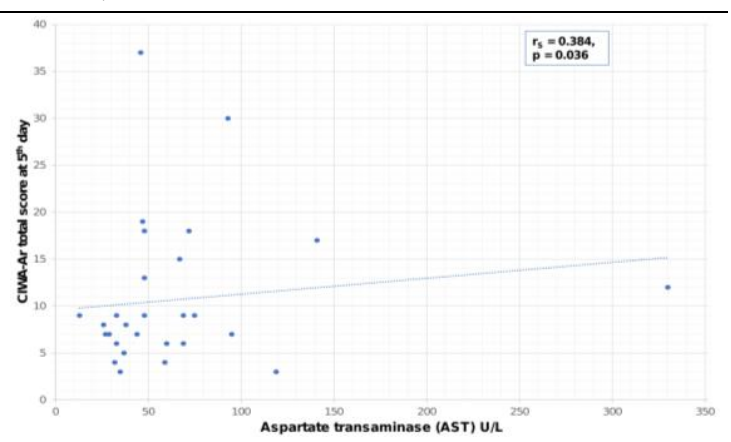

Figure 5.

Correlation between CIWA-Ar score at day 5 and AST levels

in a dosage that exerts a hypnotic and anxiolytic effect only and not as an antidepressant, acting as an antagonist of histaminergic $\mathrm{H} 1$ and $\alpha 1$-adrenergic receptors at this dose [21]. The association of different psychotropic classes did not differ between those treated with clonidine and those without clonidine $(p>0.05)$ (Table II)

Table II

Psychotropic medications used in the pharmacological treatment stratified by the presence or absence clonidine during the studied period

\begin{tabular}{lccc}
\hline \multicolumn{1}{c}{ Associated psychotropics, $\mathbf{n}(\%)$} & With clonidine $(\mathbf{n}=\mathbf{1 1})$ & Without clonidine $(\mathbf{n = 1 9})$ & Statistical significance \\
\hline Benzodiazepines and hypnotics, 26 (86.7\%) & $11(100.0 \%)$ & $15(78.9 \%)$ & $\mathrm{p}=0.268$ \\
Antidepressants, 20 (66.7\%) & $9(81.8 \%)$ & $11(57.9 \%)$ & $\mathrm{p}=0.180$ \\
Antipsychotics, 13 (43.3\%) & $5(45.5 \%)$ & $8(42.1 \%)$ & $\mathrm{p}=0.858$ \\
Anticonvulsants, 19 $(63.3 \%)$ & $8(72.7 \%)$ & $11(57.9 \%)$ & $\mathrm{p}=0.417$ \\
\hline
\end{tabular}

Note: The confidence interval (CI) is $95 \%$; The listed percentages are reported to either strata considered separately.

Regarding the efficacy of other psychotropic drugs, other than clonidine, in ameliorating symptomatology of AWS, it is noteworthy that although these have generally induced a decrease in global CIWA-Ar scores at 5 days, there was no statistically significant difference according to each class of medication (Table III). However, without reaching statistical significance it seems that trazodone, an antidepressant, tended to decrease CIWA-Ar scores at 5 days more than other psychotropics [22].

Table III

The differences in the average CIWA-Ar scale total scores at 5th day of hospitalization depending on the presence or absence of different psychotropic medications in treatment schema

\begin{tabular}{lccc}
\hline \multicolumn{1}{c}{ Associated psychotropics (mean doses) } & Absent & Present & Significance \\
\hline Benzodiazepines and hypnotics (16.35 mg equivalent doses of diazepam/24 h) & $15.25(14.523)$ & $9.96(6.296)$ & $\mathrm{p}=0.207$ \\
Trazodone $(54.54 \mathrm{mg} / 24 \mathrm{~h})$ & $12.26(9.024)$ & $7.91(3.506)$ & $\mathrm{p}=0.073$ \\
Tianeptine $(33.33 \mathrm{mg} / 24 \mathrm{~h})$ & $11.00(7.894)$ & $8.50(6.856)$ & $\mathrm{p}=0.555$ \\
Antipsychotics $(198.08 \mathrm{mg}$ equivalent doses of chlorpromazine/24 h) & $11.35(9.354)$ & $9.77(5.019)$ & $\mathrm{p}=0.586$ \\
Carbamazepine $(515.62 \mathrm{mg} / 24 \mathrm{~h})$ & $11.64(8.898)$ & $9.81(6.666)$ & $\mathrm{p}=0.526$ \\
Gabapentin $(600.00 \mathrm{mg} / 24 \mathrm{~h})$ & $9.73(6.096)$ & $16.75(14.385)$ & $\mathrm{p}=0.403$ \\
Benzodiazepines and hypnotics $(16.35 \mathrm{mg}$ equivalent doses of diazepam/24 h) & $15.25(14.523)$ & $9.96(6.296)$ & $\mathrm{p}=0.207$ \\
\hline Note: The confidence interval (CI) is $95 \%$; The listed percentages are reported to either strata considered separately &
\end{tabular}

The efficacy of clonidine in managing AWS symptoms at day 5 as measured by CIWA-Ar scale

The clonidine treatment was administered under strict blood pressure and heart rate monitoring to $11(36.7 \%)$ of the 30 total subjects. At baseline, the difference in CIWA-Ar scores between those with and without clonidine treatment was not statistically significant. However, the difference reached statistical significance after 5 days of clonidine treatment $(\mathrm{p}=0.01)$ (Figure 6 ).
Regarding the family history of probable psychopathological conditions in first-degree relatives of the subjects, $18(60 \%)$ declared that at least one family member had had alcohol use disorders, 1 (3\%) selfreported at least one family member suffering from a mood or anxiety-related disorders and 11 (37\%) selfreported no positive psychopathologic condition in their family history. These results are in line with other reports from the literature [23]. We consider that educational and sociocultural factors increase 
the risk for alcohol use disorders in individuals that are genetically predisposed.

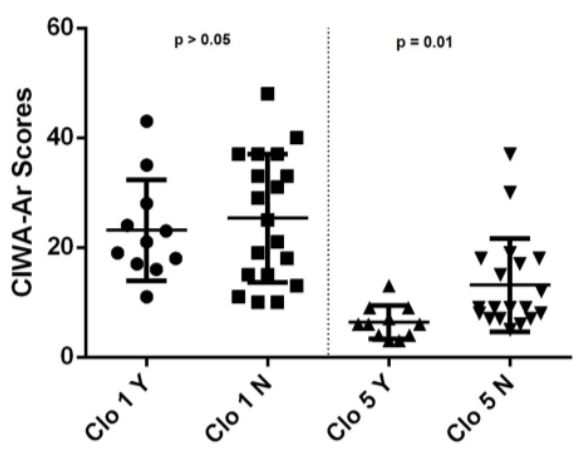

Figure 6.

CIWA-Ar scores dynamics at baseline and day 5 stratified by clonidine use (Clo 1 - clonidine at baseline; Clo 5 - clonidine at day 5; $\mathrm{Y}$ - yes; $\mathrm{N}-$ no)

At baseline, the correlation with GGT and ALT is suggestive of the fact that the severity of AWS is correlated to the degree of liver function impairment. On the other hand, increased catecholamine activity in AWS activates the sodium-potassium ATPase pump causing hypokalaemia. Hence, the AWS severity correlated with autonomous nervous system activity could be reflected in the potassium blood levels. Similar data was previously reported by others [24, 25]. Somehow expectedly, at the 5th day of continuous AWS symptoms, the elevated blood level of AST has become significantly positively correlated with the severity of clinical status. Probably, its increasing tendency stems from skeletal muscles that might be a biological marker of the progressive intensity of tremulous as a specific symptom of AWS. The role of AST in predicting the severity of AWS was also evidenced by another study [26].

Concerning the psychotropics used in the treatment of AWS patients, this was in line with our institutional therapeutic protocols, mostly overlapping with pharmacological strategies existing in other current national guidelines [27, 28]. However, although without reaching statistical significance, there are two results worth mentioning. First, the largest difference between CIWA-Ar mean scores at day 5 was due to the presence of trazodone in the treatment schema. Trazodone efficacy could be explained through the added sympatholytic effect by the antagonism on the $\alpha 1$ adrenergic receptor, confirmed by another previous report [29]. Secondly, gabapentin was associated with an increased CIWA-Ar score at day 5 in our study. An increased dose of gabapentin could contribute to altering the mental state, especially in vulnerable patients. This result is also supported by another research [30].

Finally, in our study, clonidine was the only medication from the therapeutic schema that was associated with a significantly lower CIWA-Ar mean score after 5 days. The efficacy of clonidine in the treatment of AWS was also confirmed by numerous previous studies, leading to its common use in medical practice [31-33]. It is worthwhile mentioning that one study revealed the fact that clonidine is effective not only in managing of AWS symptoms, but also in sustaining alcohol abstinence for extended periods [34].

\section{Conclusions}

The biological markers analysed in the present study might have a predictive value for the severity of AWS. Furthermore, hydro electrolytic rebalancing along with liver function support should represent key therapeutic objectives in the therapeutic management of AWS

The efficacy of trazodone in alleviating AWS symptoms is worth considering by further larger studies, especially due to its increased tolerability and safety in alcoholic patients.

Clonidine represents a valuable therapeutic resource for the remission of autonomous nervous system related symptoms of AWS, having a rapid onset of the therapeutic effect. Therefore, clonidine use should be included in the therapeutic protocols of AWS in eligible patients.

\section{Conflict of interest}

The authors declare no conflict of interest.

\section{References}

1. World Health Organization. Global status report on alcohol and health 2018 (Romania), available at: https://apps.who.int.

2. Bonea M, Miclutia IV, New development in treatment of alcohol use disorder. Farmacia, 2019; 67(2): 213-217.

3. Enatescu VR, Bernad E, Gluhovschi A, Papava I, Romosan R, Palicsak A, Munteanu R, Craina M, Enatescu I, Perinatal characteristics and mother's personality profile associated with increased likelihood of postpartum depression occurrence in a Romanian outpatient sample. J Ment Health., 2017; 26(3): 212219.

4. Enatescu I, Craina M, Gluhovschi A, Giurgi-Oncu C, Hogea L, Nussbaum LA, Bernad E, Simu M, Cosman D, Iacob D, Marinescu I, Enatescu VR, The role of personality dimensions and trait anxiety in increasing the likelihood of suicide ideation in women during the perinatal period. J Psychosom Obstet Gynaecol., 2020: 1-11. doi: 10.1080/0167482X. 2020.1734790 .

5. Udrea AM, Puia A, Shaposhnikov S, Avram S, Computational approaches of new perspectives in the treatment of depression during pregnancy. Farmacia, 2018; 66(4): 680-687.

6. Dixit D, Endicott J, Burry L, Ramos L, Yeung SY, Devabhakthuni S, Chan C, Tobia A, Bulloch MN, Management of Acute Alcohol Withdrawal Syndrome in Critically Ill Patients. Pharmacotherapy, 2016; 36(7): 797-822. 
7. Sarff M, Gold JA, Alcohol withdrawal syndromes in the intensive care unit. Crit Care Med., 2010; 38(9 Suppl): S494-501.

8. Giovannitti JA Jr, Thoms SM, Crawford JJ, Alpha2 adrenergic receptor agonists: a review of current clinical applications. Anesth Prog., 2015; 62(1): 31-39.

9. Balldin J, Berggren U, Engel J, Lindstedt G, Sundekler A, Walinder J, Alpha-2-adrenoceptor Sensitivity in Early Alcohol Withdrawal. Biol Psychiatry, 1992; 31: 712-719.

10. Winshenker D, Schroeder JP, There and back again: a tale of norepinephrine and drug addiction. Neuropsychopharmacology, 2007; 32: 1433-1451.

11. Patkar AA, Gopalakrishnan R, Naik PC, Murray HW, Vergare MJ, Marsden CA, Changes in plasma noradrenalin and serotonin levels and craving during alcohol withdrawal. Alcohol, 2003: 38; 224-231.

12. Le AD, Harding S, Juzych W, Funk D, Shahm Y, Role of $\alpha-2$ Adrenoceptor in stress-induced reinstatement of alcohol seeking and alcohol self-administration in rats. Psychopharmacology (Berl), 2005; 179: 366-373.

13. Schmidt KT, Weinshenker D, Adrenaline rush: the role of adrenergic receptors in stimulant-induced behaviors. Mol Pharmacol., 2014; 85: 640-650.

14. Cushman P Jr, Clonidine and alcohol withdrawal. Adv Alcohol Subst Abuse, 1987; 7: 17-28.

15. Yu E, Miotto K, Akerele E, Montgomery A, Elkashef A, Walsh R, Montoya I, Fischman MW, Collins J, McSherry F, Boardman K, Davies DK, O'Brien CP, Ling $\mathrm{W}$, Kleber $\mathrm{H}$, Herman $\mathrm{BH}$, A Phase 3 placebocontrolled, double-blind, multi-site trial of the alpha-2adrenergic agonist, lofexidine, for opioid withdrawal. Drug Alcohol Depend., 2008; 97(1-2): 158-168.

16. Zhan Y, Zhang $H$, Han Z, Protective effect of dexmedetomidine combined with ulinastatin on myocardium in patients undergoing valve replacement. Farmacia, 2019; 67(3): 437-441.

17. Nikolic K, Agbaba D. Imidazoline antihypertensive drugs: selective i(1) -imidazoline receptors activation. Cardiovasc Ther., 2012; 30(4): 209-216.

18. Edwards LP, Brown-Bryan TA, McLean L, Ernsberger P. Pharmacological properties of the central antihypertensive agent, moxonidine. Cardiovasc Ther., 2012; 30: 199-208.

19. World Health Organization. ICD-10 classifications of mental and behavioural disorder: Clinical descriptions and diagnostic guidelines. Geneva: World Health Organization 1992; 195.

20. Sullivan JT, Sykora K, Schneiderman J, Naranjo CA, Sellers EM, Assessment of alcohol withdrawal: The revised Clinical Institute Withdrawal Assessment for Alcohol scale (CIWA-Ar). Brit J Addiction, 1989; 84: 1353-1357.

21. Settimo L, Taylor D, Evaluating the dose-dependent mechanism of action of trazodone by estimation of occupancies for different brain neurotransmitter targets. J Psychopharmacol., 2018; 32: 96-104.

22. Ageu LS, Levai CM, Andreescu NI, Grigoraş ML, Hogea LM, Chiriac DV, Folescu R, Bredicean AC, Nussbaum LM, Enatescu VR, Poroch V, Lupu V,
Puiu M, Nussbaum LA, Modern molecular study of weight gain related to antidepressant treatment: clinical implications of the pharmacogenetic testing. Rom J Morphol Embryol., 2018; 59(1): 165-173.

23. Powers G, Berger L, Fuhrmann D, Fendrich M, Family history density of substance use problems among undergraduate college students: Associations with heavy alcohol use and alcohol use disorder. Addict Behav., 2017; 71: 1-6.

24. Goodson CM, Clark BJ, Douglas IS, Predictors of severe alcohol withdrawal syndrome: a systematic review and meta-analysis. Alcohol Clin Exp Res., 2014; 38: 2664-2677.

25. Eyer F, Schuster T, Felgenhauer N, Pfab R, Strubel T, Saugel B, Zilker T, Risk assessment of moderate to severe alcohol withdrawal-predictors for seizures and delirium tremens in the course of withdrawal. Alcohol Alcohol, 2011; 46: 427-433.

26. Findley JK, Park LT, Siefert CJ, Chiou GJ, Lancaster RT, Demoya M, Gervasini A, Velmahos GC, Two routine blood tests-mean corpuscular volume and aspartate aminotransferase-as predictors of delirium tremens in trauma patients. J Trauma, 2010; 69: 199-201.

27. Maldonado JR, Novel Algorithms for the Prophylaxis and Management of Alcohol Withdrawal SyndromesBeyond Benzodiazepines. Crit Care Clin., 2017; 33: 559-599.

28. Dixit D, Endicott J, Burry L, Ramos L, Yeung SY, Devabhakthuni S, Chan C, Tobia A, Bulloch MN, Management of acute alcohol withdrawal syndrome in critically ill patients. Pharmacotherapy, 2016; 36: 797-822.

29. Borras L, de Timary P, Constant EL, Huguelet P, Eytan A, Successful treatment of alcohol withdrawal with trazodone. Pharmacopsychiatry, 2006; 39: 232.

30. Fleet JL, Dixon SN, Kuwornu PJ, Dev VK, MonteroOdasso M, Burneo J, Garg AX, Gabapentin dose and the 30-day risk of altered mental status in older adults: A retrospective population-based study. PLoS One, 2018; 13: 1-14.

31. Buell D, Filewod N, Ailon J, Burns KEA, Practice Patterns in the Treatment of Patients With Severe Alcohol Withdrawal: A Multidisciplinary, CrossSectional Survey. J Intensive Care Med., 2020; 35(11): 1250-1256.

32. Dobrydnjov I, Axelsson K, Berggren L, Samarütel $\mathrm{J}$, Holmström B, Intrathecal and oral clonidine as prophylaxis for postoperative alcohol withdrawal syndrome: A randomized double-blinded study. Anesth Analg., 2004; 98: 738-744.

33. Dyal S, Mac Laren R, The Assessment and Management Practices of Acute Alcohol Withdrawal: Results of a Nationwide Survey of Critical Care Pharmacists. Hosp Pharm., 2019; 54: 22-31.

34. Berggren U, Eriksson M, Fahlke C, Sundkler A, Balldin $\mathrm{J}$, Extremely long recovery time for the sedative effect of clonidine in male type 1 alcohol-dependent subjects in full sustained remission. Alcohol, 2002; 28: 181-187. 